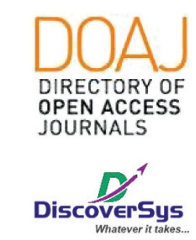

Published by DiscoverSys

\section{Efektivitas ekstrak metanol akar pandan wangi (Pandanus amaryllifolius Roxb.) Sebagai antimalaria terhadap jumlah limfosit dalam darah mencit (Mus musculus) yang diinfeksi Plasmodium berghei}

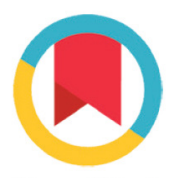

CrossMark

\author{
Danang Mustofa, ${ }^{1}$ Muhammad Ibnu Kahtan, ${ }^{1}$ Diana Natalia, ${ }^{1}$ \\ Mistika Zakiah, ${ }^{1}$ Ari Widiyantoro, ${ }^{2 *}$
}

\section{ABSTRACT}

Malaria is a infectious disease cause by protozoa with genus Plasmodium that is transmitted by female Anopheles mosquito. Our immune system which is role by lymphocyte works specifically when body infected by Plasmodium. The secondary metabolites of Pandan Wangi roots (Pandanus amaryllifolius Roxb.) possess as antimalaria. The purpose of this research to know the activity of methanol exctract from roots of Pandan Wangi (Pandanus amaryllifolius Roxb.) as antimalaria on white male mice (Mus muscullus) lymphocyte count infected by Plasmodium berghei. This is a true experimental in vivo with completely randomized design. Antimalaria effect test used methanol extract from roots of Pandan Wangi with concentration 6.5\%, 13\% and 26\%. Positive control group was given $3.74 \mathrm{mg} / \mathrm{mL}$ DHP (DihydroartremisininPiperaquin), normal control group was not given any intervention, negative control group was given aquadest. Results of this research show extract with concentration $6.5 \%, 13 \%$ and $26 \%$ have the antimalaria effect show by the decrease of parasitemia percentage. In addition, concentration of $26 \%$ extract can increase the number of lymphocytes significantly. Extract of Pandan Wangi Roots have antimalaria effect and can increase the number of lymphocytes with the best concentration of $26 \%$. The decreasing number of parasitemia level is not directly related to the increasing of lymphocyte
'Program Studi Pendidikan Dokter, Fakultas Kedokteran, Universitas Tanjungpura, Pontianak 2Program Studi Kimia, Fakultas MIPA, Universitas Tanjungpura, Pontianak

*Korespondensi: Ari Widiyantoro, Program Studi Kimia, Fakultas MIPA, Universitas Tanjungpura, Pontianak ariyant2@yahoo.com
Keywords: Antimalaria, lymphocyte, Pandanus amaryllifolius Roxb, Plasmodium berghei

Cite This Article: Mustofa, D., Kahtan, M.I., Natalia, D., Zakiah, M., Widiyantoro, A. 2019. Efektivitas ekstrak metanol akar pandan wangi (Pandanus amaryllifolius Roxb.) Sebagai antimalaria terhadap jumlah limfosit dalam darah mencit (Mus musculus) yang diinfeksi Plasmodium berghei. Intisari Sains Medis 10 (2): 489-496. D0I: 10.15562/ism.v10i2.366

\section{ABSTRAK}

Malaria adalah penyakit infeksi yang disebabkan oleh protozoa dengan genus Plasmodium yang ditularkan melalui nyamuk Anopheles betina. Sistem pertahanan tubuh yang diperankan oleh limfosit akan bekerja secara spesifik ketika tubuh terinfeksi Plasmodium. Kandungan metabolit sekunder pada akar tanaman pandan wangi (Pandanus amaryllifolius Roxb.) mempunyai kemampuan bekerja sebagai antimalaria. Tujuan penelitian ini adalahmengetahuiefektivitas ekstrakakarpandan wangi(Pandanus amaryllifolius Roxb.) sebagai antimalaria terhadap jumlah limfosit dalam darah Mencit (Mus muscullus) yang diinfeksi Plasmodium berghei. Penelitian ini merupakan penelitian eksperimental murni secara in vivo dengan rancangan complete randomized design.
Uji efektivitas antimalaria menggunakan ekstrak metanol akar pandan wangi dengan konsentrasi 6,5\%, 13\% dan 26\%. Kontrol positif diberi 3,74 mg/mL DHP (Dihydroartremisinin-Piperaquin), kontrol normal tidak diintervensi, sedangkan kontrol negatif diberi akuades. Hasil penelitian menunjukkan bahwa konsentrasi ekstrak 6,5\%, 13\% dan 26\% memiliki aktivitas antimalaria dengan penurunan persentase parasitemia. Selain itu konsentrasi ekstrak 26\% mampu meningkatkan jumlah limfosit secara signifikan. Ekstrak akar pandan wangi memiliki aktivitas antimalaria dan mampu meningkatkan jumlah limfosit dengan konsentrasi paling baik $26 \%$ serta tidak ada berhubungan langsung antara penurunan tingkat parasitemia dan peningkatan jumlah limfosit. 


\section{PENDAHULUAN}

Malaria adalah penyakit yang banyak dijumpai terutama bagi orang yang tinggal di daerah endemik dan di sekitar breeding place (tempat perindukan utama). ${ }^{1} \quad$ Malaria disebabkan oleh protozoa dengan genus Plasmodium dan nyamuk Anopheles betina berperan sebagai vektor melalui gigitnya. Plasmodium vivax, Plasmodium falciparum, Plasmodium malariae dan Plasmodium ovale merupakan beberapa spesies dari Plasmodium yang menginfeksi manusia. ${ }^{2}$

Menurut pemaparan World Health Organization (WHO) dalam World Malaria Report 2015 diperkirakan terjadi 214 juta kasus malaria di tahun 2015 dengan angka kematian 438.000 jiwa. Afrika menempati urutan pertama dengan persentase $88 \%$ dari total jumlah kasus yang terjadi di tahun 2015 . Urutan kedua serta ketiga di tempati oleh Asia dan Mediterania dengan persentase kejadian secara berurutan masing-masing $10 \%$ dan $2 \%$ dari total jumlah kasus yang dilaporkan. ${ }^{3}$

Laporan kasus kejadian malaria tahun 2014 menunjukan bahwa Indonesia merupakan salah satu dari tiga negara di Asia dengan jumlah kasus malaria terbanyak, bersama India dan Myanmar. ${ }^{3,4}$ Data Indonesia menunjukan sebanyak 396 kabupaten/kota merupakan daerah endemis malaria. Setelah dilakukan stratifikasi berdasarkan API (Annual Parasite incidence), Indonesia bagian timur serta beberapa wilayah di Kalimantan tergolong dalam stratifikasi malaria tinggi. ${ }^{5}$ Angka kejadian malaria di Kalimantan Barat masih cukup tinggi. Data tahun 2014 menunjukan terdapat sekitar 4.546.439 jiwa populasi yang berisiko malaria dan 753 jiwa dinyatakan positif malaria. ${ }^{6,7}$ Berdasarkan angka tersebut maka diperlukan langkah pencegahan dan penanganan yang efektif agar angka kejadian kasus dan kematian akibat terinfeksi malaria dapat menurun.

Adanya infeksi pada tubuh akan menstimulasi serangkaian respon imun yang dimulai dari respon imun nonspesifik yang diperankan oleh makrofag, monosit, netrofil dan eosinofil kemudian dilanjutkan respo imun spesifik oleh limfosit. Limfosit merupakan sel pertahanan tubuh yang berkerja secara spesifik. Poliferasi dan diferensiasi limfosit akan mencapai puncaknya pada hari ke 7-14 pasca terinfeksi. Pajanan oleh APC akan menstimulasi poliferasi dan diferensiasi limfosit menjadi sel $\mathrm{T}$ yaitu sel $\mathrm{T}$ CD4+ (Th1 dan Th2) dan sel $\mathrm{B}$ yang menghasilkan berbagai subtipe antibodi. ${ }^{8,9,10}$

Artemisinin monotherapy telah ditetapkan sebagai terapi malaria tanpa komplikasi oleh WHO pada tahun 2006. Sementara beberapa obat baru seperti artemisinin combination therapy (ACT) telah dipakai terutama di daerah endemik malaria. ${ }^{11}$ Penggunaan atremisinin telah dilaporkan terjadi resistensi, laporan kasus resistensi artemisinin terhadap infeksi Plasmodium sp. telah dilaporkan diberbagai negara seperti Cambodia, Myanmar, Thailand dan Vietnam. ${ }^{3}$ Oleh sebab itu maka perlu dikembangkan obat alternatif antimalaria yang baru, salah satunya dengan memanfaatkan sumber dari alam (herbal) sekitar seperti tanaman pandan wangi (Pandanus amaryllifolius Roxb.) yang mudah dijumpai di daerah tropis maupun subtropis tidak terkecuali di Indonesia. Tanaman ini dikenal memiliki bau yang harum (aromatik) dan bersifat sejuk. Kandungan kimia tanaman ini adalah alkaloid, steroid, terpenoid, saponin, flavonoid, tanin, polifenol dan zat warna. Masyarakat mengenal tanaman ini berkhasiat untuk pengobatan tradisional. ${ }^{12,13}$

Penelitian sebelumnya yang dilakukan Widiyantoro pada tahun 2014 menyebutkan bahwa ekstrak metanol akar pandan wangi (Pandanus amaryllifolius Roxb.) mengandung senyawa golongan alkaloid yang mempunyai gugus lakton (alkaloid lakton). Senyawa ini secara teoritis mempunyai pontensi sebagai antimalaria dan mempunyai mekanisme kerja menyerupai obat antimalaria. ${ }^{13}$ Alkaloid juga dikenal sebagai senyawa immunostimulan yang dapat mempengaruhi sistem imun. ${ }^{14}$ Penelitian lain menunjukan senyawa alkaloid mampu menghambat pertumbuhan skizon Plasmodium sp., dengan cara menghambat sintesis protein parasit yang berlangsung pada tahap trofozoit. ${ }^{15}$

Aktivitas ekstrak akar pandan wangi sebagai antimalaria telah diketahui, tetapi belum diketahui apakah sistem imun hospes juga terpengaruh oleh bahan yang aktif berkerja sebagai antimalaria. Diperlukan penelitian lebih lanjut tentang apakah efektivitas ekstrak akar pandan wangi sebagai antimalaria melibatkan faktor imun hospes (mencit yang diinfeksi Plasmidium berghei).

\section{METODE}

Penelitian ini merupakan penelitian true experimental (eksperimental murni) dengan pendekatan desain penelitian Completely Randomized Design (rancang acak lengkap). Peneliti memberikan perlakuan pada sampel berupa hewan coba di laboratorium. Hewan coba yang digunakan adalah mencit (Mus musculus) yang berusia 8-12 minggu bulan dengan berat $\pm 25-40$ gram. Mencit dikelompokkan menjadi 5 kelompok perlakuan dan 1 kelompok tanpa perlakuan, dimana masingmasing kelompok terdiri dari 5 mencit. Penelitian ini telah mendapatkan ethical clearance dari Fakultas Kedokteran Universitas Tanjungpura 
dengan nomor 1332/UN22.9/DT/2017.

Sampel yang digunakan adalah akar tanaman pandan wangi yang didapatkan dari daerah Gamping, Yogyakarta dan sudah diidentifikasikan di Laboratorium Taksonomi Fakultas Biologi Universitas Gadjah Mada. Akar kemudian dibersihkan, selanjutnya diblender menjadi serbuk. Serbuk akar pandan wangi sebanyak $1 \mathrm{~kg}$ dibersihkan kembali dengan diayak kemudian dikeringkan pada suhu kamar selama beberapa hari (dengan indikator kadar air $<10 \%$ ) sehingga sampel yang didapatkan sampel sebanyak 450 g. Selanjutnya sampel kering sebanyak $450 \mathrm{~g}$ dimaserasi dengan metanol $80 \%$ pada suhu kamar selama 3x24 jam. Kemudian ekstrak disaring dan filtratnya dikumpulkan. Residu dimaserasi kembali dengan cara menambahkan metanol yang baru (sampai jernih). Seluruh filtrat dikumpulkan lalu dilakukan uji skrining fitokimia dan dipekatkan dengan evaporator, setelah itu ditimbang untuk mengetahui rendemennya. Ekstrak kasar metanol kemudian difraksinasi menjadi fraksi metanol. Kemudian ekstrak kental metanol dan hasil partisi dilakukan uji aktivitas antimalaria terhadap jumlah limfosit pada mencit Mus musculus yang diinjeksi Plasmodium berghei.

Proses transfer atau inokulasi Plasmodium berghei pada mencit uji di dapat dari 6 mencit donor yang sudah diinfeksikan $\pm 1 \times 10^{9}$ Plasmodium berghei. Plasmodium berghei yang telah mencapai $>10 \%$ parasitemia di dalam tubuh mencit pendonor akan siap dilakukan inokulasi pada mencit uji. Adapun eritrosit yang terinfeksi parasit Plasmoidum berghei akan di resuspensikan dalam larutan PBS sebagai media sel hidup dan pengencer dari darah mencit pendonor yang akan diinokulasikan kembali pada mencit uji, kemudian diinjeksikan pada mencit pendonor sebanyak 0,2 $\mathrm{mL}$ secara intraperitoneal.

Inokulasi Plasmodium berghei dilakukan secara intra-peritoneal, jika derajat parasitemia 1 mencit donor sebesar $>10 \%$ maka darah diambil sebesar $2 \mathrm{~mL}$, campur dengan larutan EDTA 1\% sebanyak $200 \mu \mathrm{l}$ dan diresuspensi dalam 1,8 mL larutan PBS. Selanjutnya dilakukan penyuntikan inokulum sebanyak 0,2 mL pada mencit uji. Selama $2 \times 24$ jam jika telah mencapai $>1 \%$ maka dilakukan terapi menggunakan obat antimalarial DHP dan ekstrak akar pandan wangi konsentrasi 6,5\%, 13\% dan $26 \%$ pada hari pertama hingga hari kelima dan dilakukan pengamatan terhadap parasitemia dan jumlah limfosit setiap hari selama 5 hari tersebut. Konsentrasi ekstrak ditentukan berdasarkan penelitian yang telah dilakukan sebelumnya oleh group riset kami. ${ }^{16}$

Perhitungan aktivitas antimalaria di lakukan dengan melihat jumlah eritrosit yang terinfeksi oleh Plasmodium berghei pada 5 lapang pandang, dengan setiap lapang pandang terdapat 200 eritrosit. Pengamatan parasitemia dilakukan setiap 2,5 jam setelah pemberian terapi ekstrak akar pandan wangi dan DHP secara oral setiap hari selama 5 hari. Pemeriksaan jumlah limfosit dengan menggunakan metode apusan darah tipis kemudian diamati dibawah mikroskop.

\section{HASIL PENELITIAN}

Identifikasi Determinasi dan Uji Metabolit Sekunder Ekstrak Metanol Akar Pandan Wangi (Pandanus amaryllifolius Roxb.)

Determinasi tumbuhan uji penelitian ini yaitu akar pandan wangi dilakukan di Laboratorium Sistematik Tumbuhan Fakultas Biologi Universitas Gadjah Mada. Hasil determinasi menunjukkan bahwa tumbuhan akar pandan pada penelitian ini diidentifikasi sebagai pandan (Pandanus amaryllifolius Roxb.). Hasil uji metabolit sekunder ekstrak metanol daun akar pandan wangi dengan metode kromatografilapis tipis (KLT) menunjukkan adanya kandungan senyawa alkaloid, triterpenoid/ steroid, flavanoid dan saponin (Lihat Tabel 1).

\section{Tingkat Parasitemia Ekstrak Metanol Akar} Pandan Wangi (Pandanus amaryllifolius Roxb.) Hasil pengamatan tingkat parasitemia pada penelitian ini menunjukkan bahwa ekstrak akar pandan wangi memiliki aktivitas sebagai antimalaria. Terlihat juga semakin tinggi konsentrasi ekstrak akar pandan maka tingkat parasitemia pada mencit uji mengalami penurunan. Adapun rerata persentase Plasmodium berghei dalam 1000 sel darah mencit selengkapnya dapat dilihat pada Tabel 2.

\section{Jumlah Limfosit Ekstrak Metanol Akar Pandan Wangi (Pandanus amaryllifolius Roxb.)}

Hasil perhitungan jumlah limfosit semua kelompok perlakuan yaitu kelompok dosis 1, dosis 2, dosis 3, kelompok kontrol negatif, kelompok kontrol positif dan kelompok normal selama 5 hari perlakuan. Hasil pengamatan jumlah limfosit pada penelitian ini menunjukkan bahwa ekstrak akar tumbuhan pandan wangi memiliki kemampuan sebagai imunostimulan pada peningkatan jumlah limfosit pada mencit yang diinfeksi Plasmodium berghei. Terlihat juga semakin tinggi konsentrasi ekstrak akar pandan maka jumlah limfosit pada mencit uji mengalami peningkatan dalam rentang normal kadar limfosit pada darah perifer terutama pada mencit kelompok kontrol positif dan normal. Adapun rerata persentase jumlah limfosit pada darah mencit. dapat dilihat pada Tabel 3. 
Tabel 1. Uji Fitokimia Menggunakan Kromatografi Lapis Tipis (KLT)

\begin{tabular}{|c|c|c|c|c|c|c|}
\hline No. & Uji & Pereaksi & Gambar & Foto UV 366nm & Dekskripsi & Hasil \\
\hline 1 & Alkaloid & Dragendorff & & & Cokelat & $(+)$ \\
\hline 2 & Saponin & Akuades & & & $\begin{array}{l}\text { Terbentuk busa yang } \\
\text { persisten selama } 10 \\
\text { menit }\end{array}$ & $(+)$ \\
\hline 3 & Flavonoid & Serium sulfat $5 \%$ & & & Kekuningan & $(+)$ \\
\hline 4 & Steroid & Liberman-burchard & & & Kehijauan & $(+)$ \\
\hline
\end{tabular}

5 Terpenoid Liberman-burchard
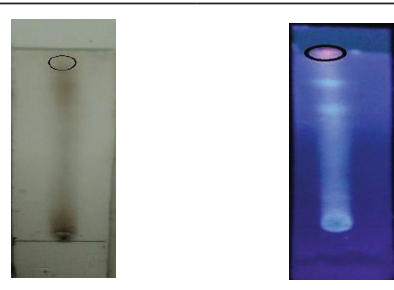

Merah muda

$(+)$
Tabel 2. Rerata persentase Plasmodium berghei selama 5 hari pada masing-masing kelompok uji

\begin{tabular}{cccccc}
\hline \multirow{2}{*}{ Hari ke } & \multicolumn{5}{c}{ Rerata Tingkat Parasitemia (\%) } \\
\cline { 2 - 6 } & Dosis I & Dosis II & Dosis III & KP & KN \\
\hline $\mathbf{1}$ & $8,7 \pm 0,9$ & $8,3 \pm 2,2$ & $6,8 \pm 1,3$ & $5,5 \pm 0,5$ & $12,7 \pm 4,7$ \\
\hline $\mathbf{2}$ & $12,0 \pm 1,1$ & $9,8 \pm 1,4$ & $7,6 \pm 2$ & $4,9 \pm 0,7$ & $20,2 \pm 6,5$ \\
\hline $\mathbf{3}$ & $11,9 \pm 1,5$ & $10,8 \pm 1,3$ & $10,8 \pm 1,1$ & $4,0 \pm 0,7$ & $32,6 \pm 8,1$ \\
\hline $\mathbf{4}$ & $9,8 \pm 2,9$ & $9,7 \pm 1,3$ & $9,6 \pm 1$ & $3,3 \pm 0,7$ & $42,4 \pm 8,1$ \\
\hline $\mathbf{5}$ & $10,6 \pm 2,5$ & $8,4 \pm 1,8$ & $8,1 \pm 1,1$ & $2,0 \pm 0,7$ & $46,7 \pm 7$ \\
\hline Rerata \% & $\mathbf{1 0 , 6}$ & $\mathbf{9 , 4}$ & $\mathbf{8 , 6}$ & $\mathbf{3 , 9}$ & $\mathbf{3 0 , 9}$ \\
\hline
\end{tabular}

Dosis I (6,5\%); Dosis II (13\%); Dosis III (26\%); KP: Kontrol Positif; KN: Kontrol Negatif
Hubungan Tingkat Parasitemia dan Jumlah Limfosit pada Masing-masing Kelompok Uji

Data selanjutnya dianalisis untuk mengetahui korelasi antara tiga variabel pada penelitian dengan menggunakan uji Spearman. Hasil uji Spearman menunjukkan korelasi lemah selama 5 hari setelah perlakuan antara tingkat parasitemia dan jumlah limfosit, dengan arah korelasi berlawanan pada hari pertama $(r=-0,127, p=0,653)$ dan ketiga $(r=$ $-0,270, p=0,330)$ serta arah korelasi searah pada hari kedua $(r=0,052, p=0,853)$, keempat $(r=0,049$, $p=0,863)$ dan kelima $(r=-0,354, p=0,196)$. Hasil ini menunjukan bahwa tidak ada hubungan langsung antara peningkatan jumlah limfosit dan penurunan tingkat parasitemia. Hubungan tingkat parasitemia dan jumlah limfosit pada setiap dosis dapat dilihat pada Grafik 1 sampai 5. 
Tabel 3. Rerata persentase jumlah limfosit selama 5 hari pada masingmasing kelompok uji

\begin{tabular}{|c|c|c|c|c|c|c|}
\hline \multirow{2}{*}{$\begin{array}{l}\text { Hari } \\
\text { ke }\end{array}$} & \multicolumn{6}{|c|}{ Rerata Jumlah Limfosit (\%) } \\
\hline & Dosis I & Dosis II & Dosis III & $\mathrm{KP}$ & $\mathrm{KN}$ & $\mathrm{N}$ \\
\hline 1 & $34,6 \pm 3,2$ & $39,8 \pm 4,6$ & $35,4 \pm 2$ & $38,2 \pm 3,9$ & $40,4 \pm 5,7$ & 52 \\
\hline 2 & $38,2 \pm 2,3$ & $44 \pm 2,9$ & $35,8 \pm 3$ & $44 \pm 4,9$ & $37,8 \pm 1,9$ & 45 \\
\hline 3 & $43,6 \pm 6,1$ & $46,6 \pm 9,8$ & $48,8 \pm 4,3$ & $45,24,3$ & $43,4 \pm 2,5$ & 54 \\
\hline 4 & $54,2 \pm 3,8$ & $56,6 \pm 5,7$ & $64,6 \pm 4$ & $53,6 \pm 4,8$ & $57,4 \pm 4,9$ & 50 \\
\hline 5 & $63,4 \pm 3,9$ & $65,4 \pm 2,5$ & $70,2 \pm 3,7$ & $64,2 \pm 3,6$ & $67,6 \pm 3$ & 53 \\
\hline $\begin{array}{c}\text { Rerata } \\
\%\end{array}$ & 46,8 & 50,48 & 50,96 & 49,04 & 49,32 & 50,8 \\
\hline
\end{tabular}

Dosis I (6,5\%); Dosis II (13\%); Dosis III (26\%); KP: Kontrol Positif; KN: Kontrol Negatif; N: Kelompok Tanpa Perlakuan

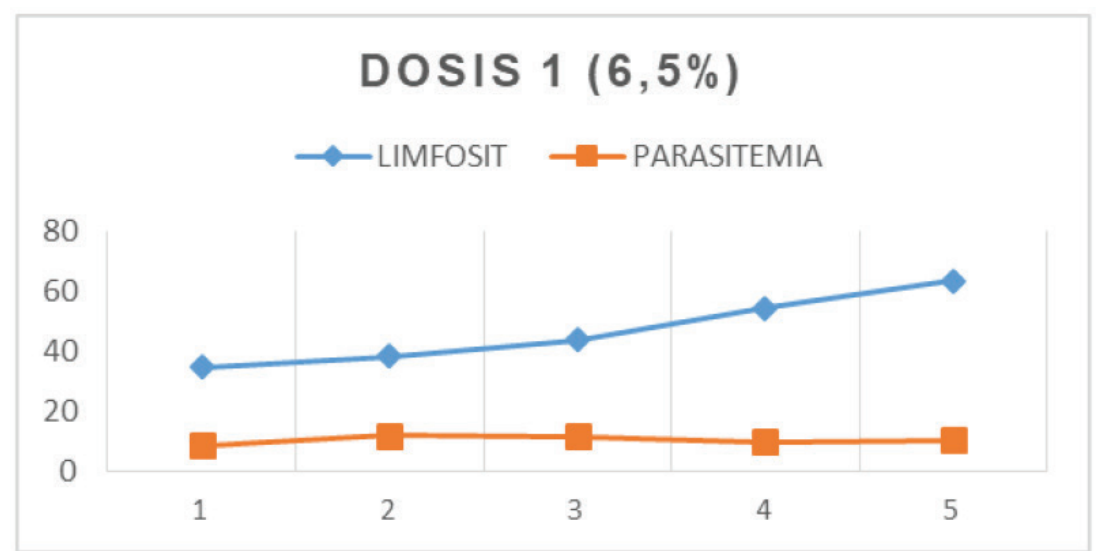

Grafik 1. Hubungan tingkat parasitemia dan jumlah limfosit pada konsentrasi $6,5 \%$

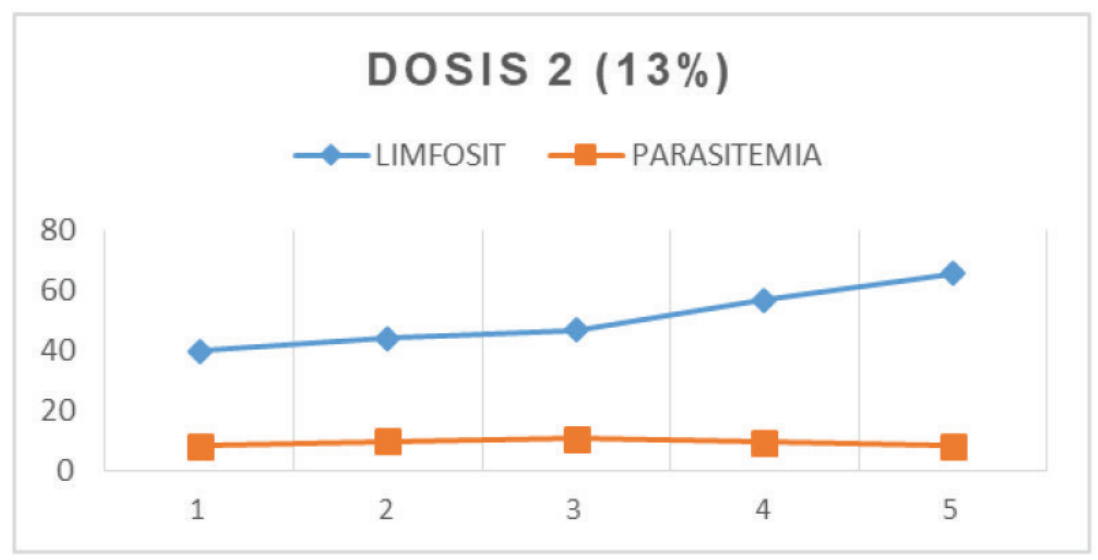

Grafik 2. Hubungan tingkat parasitemia dan jumlah limfosit pada konsentrasi $13 \%$

\section{PEMBAHASAN}

Metabolit Sekunder Ekstrak Metanol Akar Pandan Wangi (Pandanus amaryllifolius Roxb.)

Hasil uji fitokimia KLT (Tabel 1) menunjukan terdapat kandungan metabolit sekunder akar pandan wangi yang berpotensi sebagai antimalaria yaitu alkaloid, flavonoid, steroid dan terpenoid. Khususnya alkaloid, pada penelitian sebelumnya alkaloid yang terkandung dalam ekstrak akar pandan wangi mempunyai gugus lakton, sehingga mempunyai mekanisme kerja yang sama dengan obat antimalaria golongan aminokuinolin. ${ }^{13}$ Mekanisme kerjanya yaitu molekul artemisinin yang mempunyai gugus seskuirterpenlakton dapat masuk ke vakuola makanan parasit kemudian struktur jembatan peroksida dalam molekul artemisinin berinteraksi dengan ferriprotoporphyrin IX (heme) membentuk radikal yang bersifat toksik dan reaktif untuk parasit. ${ }^{17,18}$

\section{Aktivitas Ekstrak Akar Pandan Wangi terhadap Tingkat Parasitemia}

Aktivitas antimalaria ekstrak akar pada wangi terlihat dari rata-rata tingkat parasitemia dari hari pertama sampai hari kelima perlakuan lebih rendah dari rata-rata tingkat parasitemia kelompok kontrol negatif. Pada kelompok perlakuan ekstrak akar pandan wangi tingkat parasitemia cenderung mengalami penurunan pada hari keempat dan kelima, sementara pada kelompok kontrol negatif mengalami peningkatan setiap hari (Tabel 2).

Pada hari pertama, kedua dan ketiga tingkat parasitemia pada kelompok perlakuan ekstrak akar pandan wangi mengalami peningkatan, hal ini diduga karena dosis perlakuan yang diberikan belum cukup sehingga kandungan metabolit sekunder ekstrak akar pandan wangi yaitu alkaloid belum mampu melawan infeksi parasit Plasmodium berghei. Penurunan baru terjadi pada hari keempat dan kelima setelah pemberian ekstrak akar pandan wangi. Pada penelitian sebelumnya didapatkan hasil sama dengan menggunakan ekstrak buah merah (Pandanus conoideus Lamk). Pada penelitian tersebut dilakukan pemberian dosis ekstrak 7,8 $\mathrm{mg} / 30$ gram berat tikus, didapatkan persentase parasitemia yang lebih rendah pada kelompok uji jika dibandingkan dengan kontrol negatif. ${ }^{19}$

Jika dibandingkan dengan kelompok kontrol positif, penurunan tingkat parasitemia setelah perlakuan ekstrak akar pandan wangi belum mampu menyamai penurunan tingkat parasitemia yang terjadi pada kelompok kontrol positif yang diberi perlakuan dengan DHP (Dihydro Artemisinin-Piperaquin) (Tabel 2). Hal ini membuktikan bahwa ekstrak akar pandan wangi memiliki aktivitas antimalaria, tetapi belum 


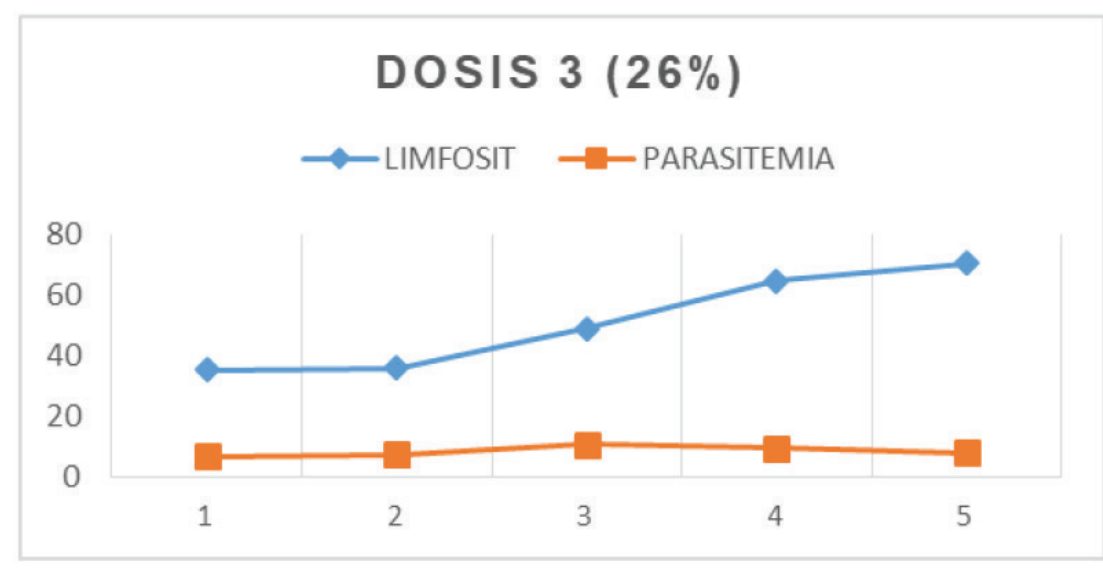

Grafik 3. Hubungan tingkat parasitemia dan jumlah limfosit pada konsentrasi $26 \%$

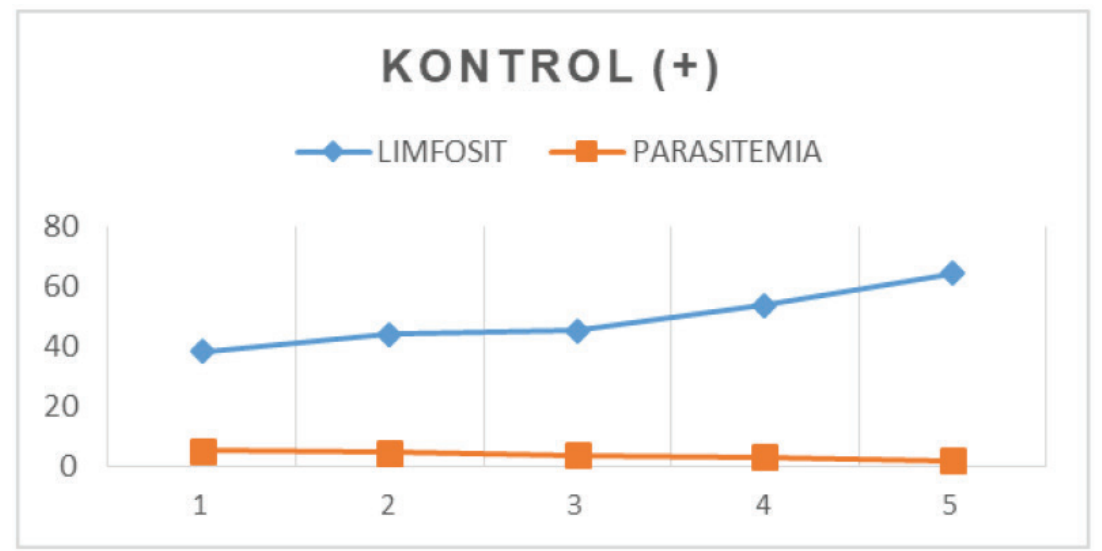

Grafik 4. Hubungan tingkat parasitemia dan jumlah limfosit pada Kontrol Positif

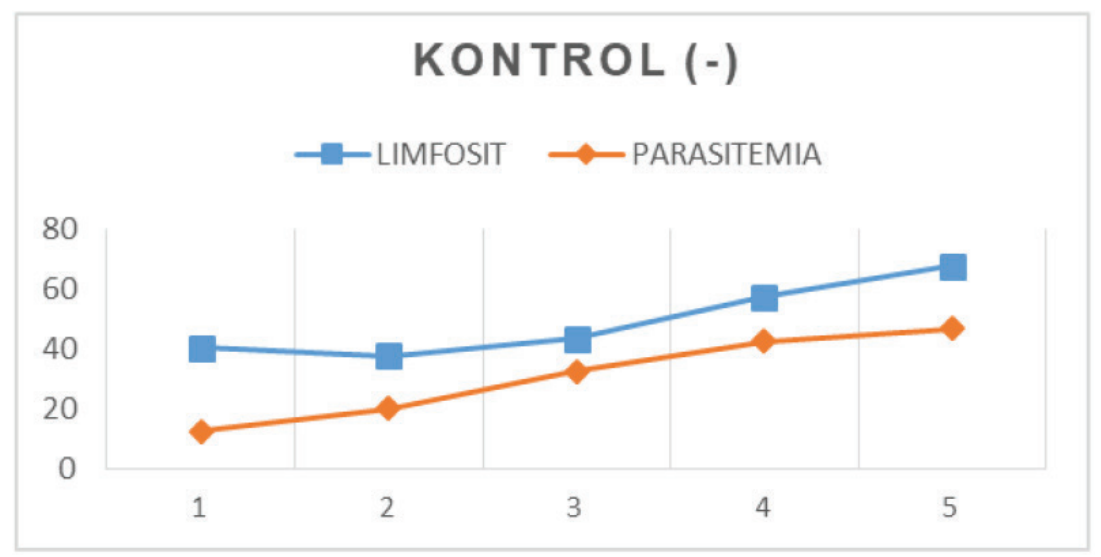

Grafik 5. Hubungan tingkat parasitemia dan jumlah limfosit pada Kontrol Negatif

mampu menggantikan DHP (Dihydro ArtemisininPiperaquin) yang merupakan obat standar untuk pengobatan penyakit malaria. Kelompok perlakuan ekstrak akar pandan wangi yang memiliki aktivitas antimalaria paling mendekati DHP adalah kelompok perlakuan konsentrasi $26 \%$ dengan rerata persentase parasitemia $8,6 \%$.

\section{Aktivitas Ekstrak Akar Pandan Wangi terhadap Jumlah Limfosit}

Nilai normal limfosit pada darah mencit berkisar antara $36-90 \%{ }^{20}$ Pada penelitian didapatkan ratarata jumlah limfosit semua kelompok mengalami peningkatan dari hari pertama sampai kelima. Pada hari pertama sampai ketiga limfosit mengalami peningkatan tetapi tidak signifikan karena pada saat tersebut sistem imun yang berkerja adalah sistem imun nonspesifik serta terjadinya aportosis limfosit. Peningkatan yang bermakna yaitu pada hari keempat, dimana kelompok perlakuan 3 dengan konsentrasi 26\% mengalami peningkatan tertinggi dibanding dengan kelompok kontrol negatif dan kontrol positif serta kelompok perlakuan 1 dan 2 dengan konsentrasi 6,5\% dan 13\%. Peningkatan ini dikarenakan respon imun spesifik yang diperankan limfosit sudah mulai berkerja dan puncaknya meningkat pada hari ke 7-14.

Pemberian ekstrak akar pandan wangi yang pada uji fitokimia KLT (Tabel 1) mempunyai kandungan metabolit sekunder berupa alkaloid dan falvonoid yang berfungsi sebagai immunostimulan menyebabkan peningkatan limfosit lebih tinggi. Dibuktikan pada kelompok perlakuan dosis 3 konsentrasi 26\% jumlah limfosit mengalami peningkatan bermakna pada hari keempat dibandingkan dengan kelompok kontrol negatif (Lihat Tabel 3.). Mekanismenya adalah alkaloid dan falvonoid meningkatkan aktivitas IL-2 dan proliferasi limfosit sehingga jumlah limfosit mengalami peningkatan. ${ }^{21}$ IL-2 akan meningkatkan poliferasi sel $\mathrm{T}$ yang nantinya akan memacu peningkatan jumlah sel imun nonspesifik dan pembentukan antibodi. ${ }^{22}$ Penelitian sebelumnya manyatakan bahwa buah merah (Pandanus conoideus Lam.) mampu meningkatkan jumlah limfosit. ${ }^{23}$ Penelitian lain menunjukan bahwa buah merah (Pandanus conoideus Lam.) mampu meningkatkan jumlah sel leukosit mononuklear. ${ }^{24}$

Dihydroartemisinin merupakan salah satu jenis obat yang terkandung dalam Artemisin combination teraphy (ACT). Dihydroartemisinin mempunyai efek imunologi yaitu mensupresi limfosit dalam darah dengan menghambat sel $\mathrm{T}$ dan sel $\mathrm{B}$. IL-2 yang terlibat dalam diferensiasi sel $\mathrm{T}$ dihambat sehingga jumlah limfosit tidak meningkat. Pada penelitian lain menunjukan respon imun humoral juga ditekan dengan menghambat poliferasi dan produksi sel B. ${ }^{22}$ Seperti pada Tabel 3. menunjukan jumlah limfosit kelompok kontrol positif lebih rendah dibandingkan dengan kelompok kontrol negatif dan kelompok perlakuan ekstrak akar pandan wangi terutama pada hari keempat dan kelima. 
Hubungan Tingkat Parasitemia dan Jumlah Limfosit

Plasmodium berghei merupakan salah satu penyebab infeksi malaria terutama pada mencit. Plasmodium berghei sama seperti spesies lainnya memiliki beberapa stadium kehidupan baik di dalam tubuh nyamuk atau pun tubuh manusia. Setelah mencit terinfeksi Plasmodium berghei serangkaian respon imun dimulai dari respon imun nonspesifik yang diperankan oleh makrofag, monosit, netrofil dan eosinofil kemudian dilanjutkan respo imun spesifik oleh limfosit. Limfosit merupakan sel pertahanan tubuh yang berkerja di fase kronis secara spesifik. Limfosit akan mengalami poliferasi dan diferensiasi yang puncaknya pada hari ke 7-14 pasca terinfeksi. Setelah terpajan oleh APC, limfosit akan berpoliferasi dan diferensiasi menjadi sel $\mathrm{T}$ khusunya yang paling banyak yaitu sel $\mathrm{T} \mathrm{CD} 4^{+}(\mathrm{Th} 1$ dan Th2). Sel Th1 berfungsi meningkatkan jumlah sel yang berkerja pada respon imun nonspesifik yang akan menghasilkan radikal bebas yang akan menghambar pertumbuhan dan mempercepat degenerasi parasit. Sementara sel Th2 merangsang poliferasi dan diferensiasi sel B yang berkerja secara spesifik menghasilkan antibodi yang sesuai dengan antigen yang terpajan. Sel $\mathrm{T} \mathrm{CD} 8^{+}$berperan sebagai efektor langsung untuk fagositosis parasit dan menghambat perkembangan parasit dengan menghasilkan IFN- $\gamma$. 23,24

Pada setiap stadium hidup Plasmodium berghei dimulaidarisporozoit, trofozoid,skizon danmerozoit memiliki antigen yang berbeda-beda. Ketika limfosit terpajan oleh antigen (misalnya stadium sporozoit) kemudian sel B menbentuk antibodi, limfosit memerlukan waktu untuk mengahasilkan antibodi yang sesuai. Namun ketika antibodi sudah terbentuk, stadium hidup Plasmodium berghei juga terus berjalan (stadium sporozoit berubah menjadi tropozoit) dan membentuk antigen baru dan tidak lagi menjadi target dari antibodi yang sudah terbentuk. Dikarenakan mekanisme kerja antibodi adalah membentuk komplek antigen-antibodi. Limfosit harus membentuk antibodi yang baru sesuai dengan antigen yang terpajan agar dapat berkerja. ${ }^{24}$ Siklus ini akan terus menerus terjadi karena Plasmodium berghei terus berubah stadium kehidupannya dan menyebabkan respon imun spesifik menjadi lama kerjanya. Tetapi limfosit memiliki sel Th1 yang bekerja meningkatkan jumlah sel imun yang berperan pada respon imun nonspesifik. Oleh karenanya limfosit berperan tidak langsung membunuh parasit malaria. Sehingga walaupun pada penelitian ini jumlah limfosit mengalami peningkatan setelah diberi ekstrak akar pandan, tetapi tidak ada korelasi secara langsung dengan penurunan tingkat parasitemia yang terjadi.
Penurunan tingkat parasitemia dikarenakan efek pemberian ekstrak akar pandan wangi yang memiliki kandungan metabolit sekunder yang berperan sebagai antimalaria serta peran limfosit meningkatkan jumlah sel imun respon imun nonspesifik.

\section{SIMPULAN}

Ekstrak akar panda wangi mempunyai aktivitas antimalaria. Konsentrasi ekstrak dengan efektivitas paling baik yaitu konsentrasi ekstrak 26\% sebagai antimalaria dan dalam peningkatan jumlah limfosit serta peningkatan jumlah limfosit tidak berhubungan langsung terhadap penurunan tingkat parasitemia. Pada penelitian selanjutnya perlu dilakukan peningkatan dosis ekstrak akar pandan wangi dan perlu memperlama waktu pengamatan serta dilakukan uji toksisitas pada akar pandan wangi.

\section{DAFTAR PUSTAKA}

1. Hasyim H, Camelia A, Fajar NA. Determinan kejadian malaria di wilayah endemis. Palembang: Universitas Sriwijaya; 2014.

2. Ananthanarayan R, Paniker CKJ. Paniker's textbook of medical parasitology seventh edition. Chennai: Orient Longman Limited; 2013.

3. WHO. World malaria report: 2015. Geneva: World Health Organization; 2015.

4. Depkes RI. Keputusan menteri kesehatan RI No.293/ MENKES/SK/IV/2009 tentang eliminasi malaria di indonesia. Jakarta: Departemen Kesehatan RI; 2009.

5. Pusat Data dan Informasi. Epidemiologi malaria di indonesia, dalam bulletin jendela data dan informasi kesehatan, triwulan 1 2011. Jakarta: Direktorat Pengendalian Penyakit Bersumber Binatang Kementrian Kesehatan RI; 2011.

6. Departemen Kesehatan RI. Status kesehatan masyarakat indonesia, survei kesehatan nasional (surkesnas) survei kesehatan rumah tangga (SKRT) 2004. Jakarta: Departemen Kesehatan RI; 2004.

7. Pusat Data dan Informasi. Jumlah kasus dan angka kesakitan malariapPer 1.000 penduduk beresiko menurut provinsi tahun 2014 dalam data dan informasi tahun 2014 (profil kesehatan indonesia). Jakarta: Kementrian Kesehatan RI; 2015.

8. Baratawidjaja GK, Rengganis. Imunologi dasar edisi ke 9. Jakarta: Balai Penerbit Fakultas Kedokteran Universitas Indonesia; 2010.

9. Fihiruddin, IN. Perbedaan jumlah sel limfosit pada penderita malaria yang terinfeksi Plasmodium falciparum dibandingkan dengan yang terinfeksi Plasmodium vivax. Media Bina Ilmial. 2013;7(4):48-51.

10. Sherwood L. Fisiologi manusia dari sel ke sistem edisi 8 . Jakarta: EGC; 2014.

11. WHO. Global report antimalaria drug efficacy and drug resistence 2000-2010. Swizerland; 2010.

12. Hariana A. Tumbuhan obat dan khasiatnya. Jakarta: Penebar Swadaya; 2013.

13. Widiyantoro A, Susilawati, Rasmiwetti. Skrining fitokimia dan aktivitas antimalaria fraksi polar akar pandan (Pandanus amaryllifolius Roxb.). 2014. [Diakses 
pada 14/08/2016] Available from: http://dppm.uii.ac.id/ dokumen/DPPM-UII_pros62_Hal_823-830_Sikring Fitokimia.pdf

14. Wagner H. Immunostimulants from medicinal plants. In Advances in Chinese medicinal materials research (Eds.) H.M. Chang; H.W. 1985.

15. Iwo MI, Pandawinata K, Siraih M, Nickel P. Efek antimalaria falciparum in vitro dan mekanisme kerja ekstrak methanol dan fraksi klorofrom korteks Aistonia scholaris (L.) R.Br dan daun cassia siamea Lamk. serta toksisitas dan isolasi alkaloid dari kortek A. schloris (L.) R.Br. [Disertasi] Program S3 Matematika dan IPA IT; 1996.

16. Irmayanti S, Widiyantoro A, Kahtan MI, Efektivitas ekstrak akar pandan wangi (Pandanus amaryllifolius Roxb) sebagai antimalarial terhadap jumlah eosinophil pada mencit (Mus musculus)yang diinfeksi Plasmodium berghei. Jurnal Cerebellum.2017 : 3 (1) :709-717

17. Bousema JT. Treatment failure of pyrimethaminesulphadoxine and induction of Plasmodium falciparum gametocytaemia in children in western kenya. Trop Med Int Health. 2003;8(5):427-50.

18. Schmuck G, Roehrdanz E, Haynes RK, Kahl R. Neurotoxic mode of action of artemisinin. Antimicrobial Agents and Chemotherapy. 2002;46(3):821-7

19. Felle ZR, Wijayanti MA, Supargiyono. The effect of Pandanus conoideus Lamk extrack to the serum level of TNF, IL-10 and parasitemia of Plamodium berghei infected in mice. Tropical Medical Journal. 2013;3(1):39-47.
20. Malole MBM dan Pramono CSU. Penggunaan hewan coba di laboratorium. Bogor: IPB; 1989.

21. Hollman PCH, Hertog MGL, Katan MB. Analysis and health effects of flavonoids. Food Chemistry. 1996;57(1):436.

22. Yao W, Wang F, dan Wang H. Immunomodulation of artemisinin and its derivatives. Sci Bull. 2016;61(18):13991406.

23. Kumala S, Kusmardi, dan Indriatmoko DD. Pengaruh ekstrak buah merah (Pandanus conoideus Lam.) terhadap pertumbuhan in vitro limfosit dan sel tumor. Departemen Patologi Anatomi FKUI. 2007. [diakses pada 24/09/2017] Available from: https://pulauherbal.com/artikel/UP_UI_ Pengaruh_Ekstrak_Buah_Merah.pdf

24. Geraldine $\mathrm{H}$ dan Dharmana E. Pengaruh pemberian minyak buah merah (Pandanus conoideus) sebelum dan selama infeksi Plasmodium berghei ANKA terhadap sel leukosit mononuklear mencit swiss. 2006. [diakses pada 1/10/2017] Available from: eprints.undip.ac.id/21278/1/ Herwinda.pdf

25. Abbas AK, Lichtman AH dan Pillai S. Cellular and molecular immunology $8^{\text {th }}$ edition. Philadelphia: Saunders Elsevier; 2015.

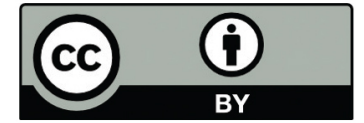

This work is licensed under a Creative Commons Attribution 